\title{
Virulence Factors and O-Serogroups Profiles of Uropathogenic Escherichia Coli Isolated from Iranian Pediatric Patients
}

\author{
Banafshe Dormanesh ${ }^{1}$; Farhad Safarpoor Dehkordi ${ }^{2}$; Sahar Hosseini ${ }^{2}$; Hassan Momtaz ${ }^{3}$; \\ Reza Mirnejad ${ }^{4}$; Mohammad Javad Hoseini ${ }^{4}$; Emad Yahaghi ${ }^{5}$; Vahideh Tarhriz ${ }^{6}$; Ebrahim \\ Khodaverdi Darian ${ }^{7 *}$ \\ ${ }_{2}^{1}$ Department of Pediatric Nephrology, AJA University of Medical Science, Tehran, IR Iran \\ 2 Young Researchers and Elites Club, Islamic Azad University, Shahrekord Branch, Shahrekord, IR Iran \\ ${ }^{3}$ Department of Microbiology, College of Veterinary Medicine, Islamic Azad University, Shahrekord Branch, Shahrekord, IR Iran \\ ${ }_{5}^{4}$ Molecular Biology Research Center, Baqiyatallah University of Medical Sciences, Tehran, IR Iran \\ 5 Young Researchers and Elite Club, North Tehran Branch, Islamic Azad University, Tehran, IR Iran \\ 6 Department of Pharmaceutical Biotechnology, Faculty of Pharmacy, Tabriz University of Medical Science, Tabriz, IR Iran \\ ${ }_{7}$ Department of Pharmaceutical Biotechnology, Faculty of Pharmacy, Tabriz University of \\ ${ }^{*}$ Corresponding Author: Ebrahim Khodaverdi Darian, Young Researchers and Elite Club, Islamic Azad University, Karaj Branch, Karaj, IR Iran. Tel/Fax: +98-26334403125, E-mail: kho- \\ daverdi_ebrahim@yahoo.com
}

Received: September 3, 2013; Revised: December 3, 2013; Accepted: December 21, 2013

Background:Uropathogenic Escherichia coli O-Serogroups with their virulence factors are the most prevalent causes of UTIs.

Objectives: The present investigation was performed to study the virulence factors and O-Serogroups profiles of UPEC isolated from Iranian pediatric patients.

Patients and Methods: This cross sectional investigation was performed on 100 urine samples collected from hospitalized pediatrics of Baqiyatallah Hospital, Tehran, Iran. Midstream urine was collected to decrease potential bacterial, cellular and artifactual contamination. All samples were cultured and those with positive results were subjected to polymerase chain reactions to detect pap, cnfi, afa, sfa and hlyA genes and various O-Serogroups.

Results: We found that 37.5\% of boys and 75\% of girls had positive results for Escherichia coli. We also found that O1 (19.33\%), O2 (13.33\%), O6 (13.33\%), O4 (11.66\%), and O18 (11.66\%) were the most commonly detected Serogroups. Totally, the serogroup of 5\% of all strains were not detected. In addition, all of these O-Serogroups were pap+, cnfl+, hlyA+, and afa+. Totally, pap (70\%), cnfi (56.66 \%), and hlyA (43.33\%) were the most commonly detected virulence genes in the both studied groups of children. The sfa (30\%) and afa (26.66\%) genes had the lowest incidence rates.

Conclusions: Special health care should be performed on UTIs management in Iranian pediatric patients. Extended researches should be performed to evaluate relation between other O-Serogroups and virulent genes.

Keywords:Uropathogenic Escherichia Coli; Pediatrics; Iran

\section{Background}

Despite all advances in medical sciences, UTIs remains as one of the most prevalent infectious diseases worldwide leading to severe disorders like cystitis and pyelonephritis (1). The average incidence rate of febrile UTIs is about $1 \%$ in boys and $3-8 \%$ in girls $(2,3)$. The Uropathogenic Escherichia coli (E. coli (UPEC)) strains are the most common causes of UTIs (4). Evaluating the potential virulence genes is required to assess the pathogenicity of UPEC strains in UTIs. Successful colonization, establishment, and ultimately leading to UTIs by UPEC strains is based on the ability to adhere to host surfaces such as mucous membranes, urinary epithelial or kidney tissue. The most important virulence factors in UPEC strains are P fimbriae (pap), a fimbrial adhesin I (afaI), hemolysin (hly), cytotoxic necrotizing factor 1 ( $\mathrm{cnf} 1$ ), and S fimbriae (sfa) (1, 4-6). Among all 174 detected E. coli O-Serogroups O7, O2, O4, O15, O6, O21, O1, O25, O16, O22, O8, O75, O18, and O83 Serogroups were previously isolated from the severe cases of UTIs (1, 4, 7-10). Unfortunately, there is a limited published data about the distribution of virulence genes and O-Serogroups in UPEC strains isolated from pediatrics with UTIs in Iran.

\section{Objectives}

This study was performed to study the distribution of virulence genes and serogroups among Iranian pediatrics with UTIs. 


\section{Materials and Methods}

\subsection{Samples Collection and Escherichia coli Iden- tification}

This cross sectional study was performed from October to December 2012. A total of 100 urine samples were collected from patients with UTIs. All of patients were younger than 3 years. All samples were collected from the hospitalized pediatrics of Baqiyatallah Governmental Hospital in Tehran, Iran. Midstream urine was collected in sterile condition to decrease potential bacterial, cellular and artifactual contamination. All samples were immediately transferred to the Biotechnology and Microbiology Research Center of the Islamic Azad University at $4^{\circ} \mathrm{C}$. Totally, $3 \mathrm{~mL}$ of each sample was blended with 225 mL of nutrient broth (Merck, Germany) for 2 min at normal speed, using a Stomacher lab blender and incubated at $37{ }^{\circ} \mathrm{C}$ for $24 \mathrm{~h}$. One milliliter sample of the nutrient broth culture was mixed with $9 \mathrm{~mL}$ of MacConkey broth (Merck, Germany) and further incubated at $37^{\circ} \mathrm{C}$ for $24 \mathrm{~h}$. One loop of each tube was streaked on MacConkey agar (Merck, Germany). A typical purple colony of E. coli was streaked on Eosin Methylene Blue agar (EMB agar) plate (Merck, Germany) and incubated at $37^{\circ} \mathrm{C}$ for $24 \mathrm{~h}$. A metallic green colony from each plate with typical E. coli morphology was selected and examined by biochemical tests, including hydrogen sulfide, citrate, urease and indole.

\subsection{DNA Isolation and E. coli Confirmation}

Bacterial strains were sub cultured overnight in LuriaBertani broth (Merck, Germany) and genomic DNA was extracted from typical colonies of E. coli using DNA extraction kit (DNPTM, CinnaGen, Iran) according to manufacturer's instruction. All of the positive colonies were confirmed using the polymerase chain reaction (PCR) technique. Table 1 shows the list of primers used for detection of 16SrRNA gene of E. coli strains isolated from pediatrics. PCR was performed with a total volume of $50 \mu \mathrm{L}$ including $2 \mathrm{mM} \mathrm{MgCl} 2,1 \mu \mathrm{M}$ of forward primer, $1 \mu \mathrm{M}$ of reverse primer, $5 \mu \mathrm{L}$ PCR buffer 10X, $200 \mu \mathrm{M}$ dNTP (Fermentas), $1 \mathrm{U}$ Taq DNA polymerase (Fermentas) and $2.5 \mu \mathrm{L}$ DNA template. The DNA was then amplified by 31 successive cycles of denaturation at $95^{\circ} \mathrm{C}$ for 45 s, primer annealing at $59^{\circ} \mathrm{C}$ for $60 \mathrm{~s}$, and DNA chain extension at $72^{\circ} \mathrm{C}$ for $60 \mathrm{~s}$.

\begin{tabular}{|c|c|c|c|c|}
\hline Serogroup & Target Gene & Primer Name & Primer Sequence (5'-3') & Size of Product, bp \\
\hline \multirow[t]{2}{*}{01} & wzX & Wl-14632 & GTGAGCAAAAGTGAAATAAGGAACG & 1098 \\
\hline & & wl-14633 & CGCTGATACGAATACCATCCTAC & \\
\hline \multirow[t]{2}{*}{06} & wzy & wl-14646 & GGATGACGATGTGATTTTGGCTAAC & 783 \\
\hline & & wl-14647 & TCTGGGTTTGCTGTGTATGAGGC & \\
\hline \multirow[t]{2}{*}{07} & wzx & wl-14648 & CTATCAAAATACCTCTGCTGGAATC & 610 \\
\hline & & wl-14649 & TGGCTTCGAGATTAAACCTATTCCT & \\
\hline \multirow[t]{2}{*}{08} & orf469 & wl-14652 & CCAGAGGCATAATCAGAAATAACAG & 448 \\
\hline & & wl-14653 & GCAGAGTTAGTCAACAAAAGGTCAG & \\
\hline \multirow[t]{2}{*}{016} & wzx & wl-14654 & GGTTTCAATCTCACAGCAACTCAG & 302 \\
\hline & & wl-14655 & GTTAGAGGGATAATAGCCAAGCGG & \\
\hline \multirow[t]{2}{*}{021} & wzx & wl-14676 & CTGCTGATGTCGCTATTATTGCTG & 209 \\
\hline & & wl-14677 & TGAAAAAAAGGGAAACAGAAGAGCC & \\
\hline \multirow[t]{2}{*}{ O75 } & wzy & wl-17413 & GAGATATACATGGGGAGGTAGGCT & 511 \\
\hline & & wl-17414 & ACCCGATAATCATATTCTTCCСААС & \\
\hline \multirow[t]{2}{*}{02} & wzy & wl-14636 & AGTGAGTTACTTTTTAGCGATGGAC & 770 \\
\hline & & wl-14637 & AGTTTAGTATGCCCCTGACTTTGAA & \\
\hline \multirow[t]{2}{*}{04} & wzx & wl-14642 & TTGTTGCGATAATGTGCATGTTCC & 664 \\
\hline & & wl-14643 & AATAATTTGCTATACССАСАСССТС & \\
\hline \multirow[t]{2}{*}{015} & wzy & wl-14672 & TCTTGTTAGAGTCATTGGTGTATCG & 183 \\
\hline & & wl-14673 & ATAAAACGAGCAAGCACCACACC & \\
\hline \multirow[t]{2}{*}{018} & wzx & wl-14656 & GTTCGGTGGTTGGATTACAGTTAG & 551 \\
\hline & & wl-14657 & CTACTATCATCCTCACTGACCACG & \\
\hline \multirow[t]{2}{*}{$\mathbf{O 2 2}$} & wzx & wl-14660 & TTCATTGTCGCCACTACTTTCCG & 468 \\
\hline & & wl-14661 & GAAACAGCCCATGACATTACTACG & \\
\hline \multirow[t]{2}{*}{025} & wzy & wl-14666 & AGAGATCCGTCTTTTATTTGTTCGC & 230 \\
\hline & & wl-14667 & GTTCTGGATACCTAACGCAATACCC & \\
\hline \multirow[t]{2}{*}{083} & wzx & wl-14668 & GTACACCAGGCAAACCTCGAAAG & 362 \\
\hline & & wl-14669 & TTCTGTAAGCTAATGAATAGGCACC & \\
\hline \multirow[t]{2}{*}{ E. coli } & 16SrRNA & wl-3110 & AGAGTTTGATCMTGGCTCAG & 919 \\
\hline & & wl-3111 & CCGTCAATTCATTTGAGTTT & \\
\hline
\end{tabular}




\subsection{O-Serogroups Amplification}

Presences of various uropathogenic O-Serogroups (O1, O4, O2, O7, O6, O15, O8, O21, O25, O16, O22, O75, O18, and O83) in UPEC strains were investigated using the PCR techniques. Used primers for O- Serogroups amplification is shown in Table 1. The PCR methods for amplification of 01, 07, 06, O21, O16, and 075 Serogroups was performed with a total volume of $50 \mu \mathrm{L}$ including 2.5 $\mathrm{mM} \mathrm{MgCl} 2,0.4 \mu \mathrm{M}$ of forward primer, $0.4 \mu \mathrm{M}$ of reverse primer, $0.4 \mu \mathrm{L}$ PCR buffer 10X, $300 \mu \mathrm{M}$ dNTP (Fermentas), $2 \mathrm{U}$ Taq DNA polymerase (Fermentas), and $3 \mu \mathrm{L}$ DNA template. The DNA was then amplified by 30 successive cycles of denaturation at $95^{\circ} \mathrm{C}$ for $30 \mathrm{~s}$, primer annealing at $55^{\circ} \mathrm{C}$ for 60 s, and DNA chain extension at $72^{\circ} \mathrm{C}$ for 60 s. Also, The PCR methods for amplification of O2, O4, O15, O18, O22, $\mathrm{O} 25$, and $\mathrm{O} 83$ serogroups was performed with a total volume of $50 \mu \mathrm{L}$ including $2.5 \mathrm{mM} \mathrm{MgCl} 2,0.6 \mu \mathrm{M}$ of forward primer, $0.6 \mu \mathrm{M}$ of reverse primer, $0.4 \mu \mathrm{L}$ PCR buffer $10 \mathrm{X}$, $300 \mu \mathrm{M}$ dNTP(Fermentas), 1.5 U Taq DNA polymerase (Fermentas), $3 \mu \mathrm{L}$ DNA template, and $3 \mu \mathrm{L}$ DMSO. The DNA was then amplified by 30 successive cycles of denaturation at $94^{\circ} \mathrm{C}$ for 60 s, primer annealing at $56^{\circ} \mathrm{C}$ for 60 s, and DNA chain extension at $72^{\circ} \mathrm{C}$ for 90 s. The programmable thermal cycler (Eppendorf, Mastercycler@ 5330, EppendorfNetheler-Hinz GmbH, Hamburg, Germany) PCR device was used in all the PCR reactions.

\subsection{Virulence Genes Amplification}

In the present study the most important virulence genes of UPEC strains including pap, afa, hlyA, cnf 1, and sfa were detected in positive samples. Table 2 shows the list of used primers for detection of UPEC virulence genes. A PCR method was performed with a total volume of 50 $\mu \mathrm{L}$ including $1.5 \mathrm{mM} \mathrm{MgCl} 2,0.4 \mu \mathrm{M}$ of forward primer, 0.4 $\mu \mathrm{M}$ of reverse primer, $5 \mu \mathrm{L}$ PCR buffer 10X, $200 \mu \mathrm{M}$ dNTP (Fermentas), 1 U Taq DNA polymerase (Fermentas), and 4 $\mu \mathrm{L}$ DNA template. The DNA was then amplified by 30 suc- cessive cycles of denaturation at $94^{\circ} \mathrm{C}$ for 60 s, primer annealing at $63^{\circ} \mathrm{C}$ for $30 \mathrm{~s}$, and DNA chain extension at $72^{\circ} \mathrm{C}$ for 90 s with a programmable thermal cycler (Eppendorf, Mastercycler® 5330, Eppendorf-Netheler-Hinz GmbH, Hamburg, Germany). All PCR products were analyzed by electrophoresis $(120 \mathrm{~V} / 208 \mathrm{~mA})$ in $1.5 \%$ agarose gel and stained by ethidium bromide. A molecular weight marker with 100 bp increments (100bp ladder, Fermentas, Germany) and $1 \mathrm{kbp}$ increments (1000bp ladder, Fermentas, Germany) was used as size standard.

\subsection{Statistical Analysis}

Chi-square test was used to assess any significant correlation between incidences of virulence factors and O-Serogroups of UPEC strains isolated from pediatrics with UTIs using SPSS software (Version 17.SPSS Inc. United States). P value below 0.05 was considered as statistically significant.

\subsection{Ethical Issues}

In the current study, we tried to protect the life, health, dignity, integrity, right to self-determination, privacy, and confidentiality of personal information of research subjects. We conform to generally accepted scientific principles, be based on a thorough knowledge of the scientific literature, other relevant sources of information, and adequate laboratory experimentation. All samples were taken from the patients who were volunteered for this research. All ethical issues were considered, and this research was performed with the hospital permission. In addition, the present study was approved by the ethical committee of Baqiyatallah Hospital, Tehran, Iran and Microbiology and Infectious Diseases Research committee of the Islamic Azad University of Shahrekord Branch, Iran. Written informed consent was obtained from all of the study patients or their parents. The ethical approval was performed on 10 October 2012 (MB612539122).

Table 2. Used Primers for Virulence Genes Amplification in Uropathogenic Escherichia Coli Strains Isolated from Pediatric Patients (Yamamoto Et Al., 1995) (12), (Le Bouguenec et al., 1992) (13)

\begin{tabular}{|c|c|c|c|}
\hline Gene & Primer Name & Primer Sequence (5'-3') & Size of Product, bp \\
\hline \multirow[t]{2}{*}{ pap } & pap3 & GCAACAGCAACGCTGGTTGCATCAT & 336 \\
\hline & pap4 & AGAGAGAGCCACTCTTATACGGACA & \\
\hline \multirow[t]{2}{*}{ cnfi } & cnf1 & AAGATGGAGTTTCCTATGCAGGAG & 498 \\
\hline & $\operatorname{cnf} 2$ & TGGAGTTTCCTATGCAGGAG & \\
\hline \multirow[t]{2}{*}{ hlyA } & hly1 & AACAAGGATAAGCACTGTTCTGGCT & 1177 \\
\hline & hly2 & ACCATATAAGCGGTCATTCCCGTCA & \\
\hline \multirow[t]{2}{*}{ sfa } & sfa1 & CTCCGGAGAACTGGGTGCATCTTAC & 410 \\
\hline & sfa2 & CGGAGGAGTAATTACAAACCTGGCA & \\
\hline \multirow[t]{2}{*}{ afa } & afa1 & GCTGGGCAGCAAACTGATAACTCTC & 750 \\
\hline & afa2 & CATCAAGCTGTTTGTTCGTCCGCCG & \\
\hline
\end{tabular}




\section{Results}

Sixty of 100 urine samples (60\%) had positive results for E. coli bacterium (Table 3). In addition, 15 of 40 boys urine samples ( $37.5 \%$ ) and 45 of 60 girls urine samples (75\%) had positive results for E. coli. All of the samples with positive results were confirmed using the PCR technique. There were significant differences $(P<0.05)$ in the incidence of UPEC strains between the girls and boys groups. The distribution of O-Serogroups in the UPEC strains isolated from boys and girls pediatric patients is shown in Table 4 . We found that $\mathrm{O} 1$ (18.33\%) had the highest incidence in urine samples of both studied groups of children, followed by 02 (18.33\%), O6 (13.33\%), O4 (13.33\%), and 018 (11.66 \%). There were no positive results for O16, and 083 Serogroups in both studied groups of children (Figures 1 and 2). Our results showed significant differences $(\mathrm{P}<0.05)$ between the incidence of $\mathrm{O} 1$ and $\mathrm{O} 15$, and also between the incidence of $\mathrm{O} 2$ and $\mathrm{O} 6$ with $\mathrm{O} 7$ and $\mathrm{O} 8$. We found that 01 Serogroup had the highest incidence of virulence genes in urine samples of boys, followed by non-detected, O2, $\mathrm{O} 18$ and $\mathrm{O} 25$ (Table 5 and Figure 3). We also found that O1 Serogroup had the highest incidence of virulence genes in urine samples of girls, followed by $\mathrm{O} 2, \mathrm{O} 6, \mathrm{O} 18, \mathrm{O} 4$, and $\mathrm{O} 25$ (Table 6). Some of the O- Serogroups of our study were pap+, cnf1+, hlyA+, afa+ and sfa+. Totally, pap was the most commonly detected putative virulence gene in the both studied groups (70\%), followed by cnfi (56.66 \%) and hlyA (43.33\%). The Sfa (30 $\%)$ and afa (26.66 \%) genes had lower distribution among various O- Serogroups. Statistical analyses showed a significant $(\mathrm{P}<0.05)$ association between the incidence of the pap gene and afa gene in the both studied groups. We also found statistically significant $(\mathrm{P}<0.05)$ association in the incidence of all studied virulence genes between O1 and 08 and 015 Serogroups.

Table 3. Distribution of Uropathogenic Escherichia Coli Isolated From Pediatric Patients in Iran

\begin{tabular}{llll}
\hline Pediatric Patients & No. Samples & Culture Positive, No. (\%) & PCR Confirmation, No. (\%) \\
\hline Boy & 40 & $15(37.5)$ & $15(37.5)$ \\
Girl & 60 & $45(75)$ & $45(75)$ \\
Total & 100 & $60(60)$ & $60(60)$ \\
\hline
\end{tabular}

Table 4. Distribution of Uropathogenic Escherichia Coli Serogroups Isolated From Pediatric Patients in Iran

\begin{tabular}{|c|c|c|c|c|c|c|c|c|c|c|c|c|c|c|c|}
\hline \multirow{2}{*}{$\begin{array}{l}\text { Pediatric } \\
\text { Patients } \\
\text { (Positive } \\
\text { Samples) } \\
\end{array}$} & \multicolumn{15}{|c|}{ O-Serogroups, No. (\%) } \\
\hline & 01 & 02 & 04 & 06 & 07 & 08 & 015 & 016 & 018 & 021 & 022 & 025 & 075 & 083 & $\begin{array}{l}\text { Non } \\
\text { Detected }\end{array}$ \\
\hline $\operatorname{Boy}(15)$ & 3 & $2(13.33)$ & $2(13.33)$ & 2 & - & - & - & - & $2(13.33)$ & - & - & $2(13.33)$ & $1(6.66)$ & - & $1(6.66)$ \\
\hline Girl (45) & $(20)$ & $6(13.33)$ & $5(11.11)$ & $(13.33)$ & $1(2.22)$ & $1(2.22)$ & $2(4.44)$ & - & $5(11.11)$ & $3(6.66)$ & $3(6.66)$ & $2(4.44)$ & $1(2.22)$ & - & $2(4.44)$ \\
\hline Total (60) & $8(17.77)$ & 8 & $7(11.66)$ & $6(13.33)$ & $1(1.66)$ & $1(1.66)$ & 2 & - & $7(11.66)$ & $3(5)$ & $3(5)$ & 4 & $2(3.33)$ & & $3(5)$ \\
\hline
\end{tabular}

\begin{tabular}{|c|c|c|c|c|c|c|c|c|c|c|c|c|c|c|c|}
\hline Gene & $01(3)$ & $02(2)$ & $04(2)$ & $06(2)$ & O7(-) & O8 (-) & $015(-)$ & $016(-)$ & O18 (2) & $021(-)$ & $022(-)$ & $025(2)$ & $075(1)$ & $083(-)$ & $\begin{array}{l}\text { Non De- } \\
\text { tected (1) }\end{array}$ \\
\hline $\operatorname{Pap}(12)$ & 3 & 2 & 1 & 1 & - & - & - & - & 2 & - & - & 2 & 1 & - & - \\
\hline $\operatorname{cnf1}(9)$ & 2 & 1 & 1 & 1 & - & - & - & - & 1 & - & - & 1 & - & - & 2 \\
\hline hlyA (8) & 2 & 1 & 1 & 1 & - & - & - & - & 1 & - & - & 1 & - & - & 2 \\
\hline Sfa (6) & 2 & 1 & - & - & - & - & - & - & 1 & 1 & - & 1 & - & - & 1 \\
\hline $\operatorname{Afa}(7)$ & 2 & 1 & 1 & 1 & - & - & - & - & 1 & - & - & 1 & - & - & - \\
\hline
\end{tabular}

Table 6. Distribution of Putative Virulence Genes in Uropathogenic Escherichia Coli O-Serogroups Isolated from Girls Patients in Iran

\begin{tabular}{|c|c|c|c|c|c|c|c|c|c|c|c|c|c|c|c|}
\hline Gene & $01(8)$ & $02(6)$ & $04(5)$ & $06(6)$ & O7 (1) & $08(1)$ & $015(2)$ & $016(-)$ & 018 (5) & 021 (3) & $022(3)$ & $025(2)$ & O75 (1) & $083(-)$ & $\begin{array}{l}\text { Non De- } \\
\text { tected (2) }\end{array}$ \\
\hline $\operatorname{Pap}(30)$ & 8 & 5 & 3 & 4 & 1 & 1 & - & - & 3 & 1 & 1 & 1 & 1 & - & 1 \\
\hline $\operatorname{cnf1}(25)$ & 6 & 4 & 2 & 3 & 1 & - & 1 & - & 2 & 1 & 1 & 1 & 1 & - & 2 \\
\hline hlyA (18) & 5 & 3 & 1 & 2 & - & 1 & 1 & - & 1 & 1 & 1 & 1 & - & - & 1 \\
\hline Sfa (12) & 3 & 2 & - & 2 & - & - & - & - & 1 & 1 & 1 & 1 & - & - & 1 \\
\hline Afa (9) & 3 & 2 & 1 & 1 & - & - & - & - & - & - & - & 1 & - & - & 1 \\
\hline
\end{tabular}




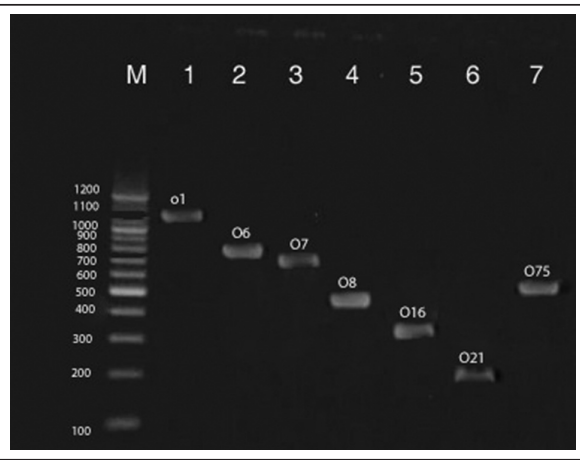

Figure 1. Multiplex PCR Assay for Detection of O1, O6, O7, 08, O16, 021 and O75 Serogroups of Uropathogenic Escherichia Coli Strains Isolated from Pediatrics With UTIs. Line M is 100 bp Ladders; 1-7 Are Positive Samples

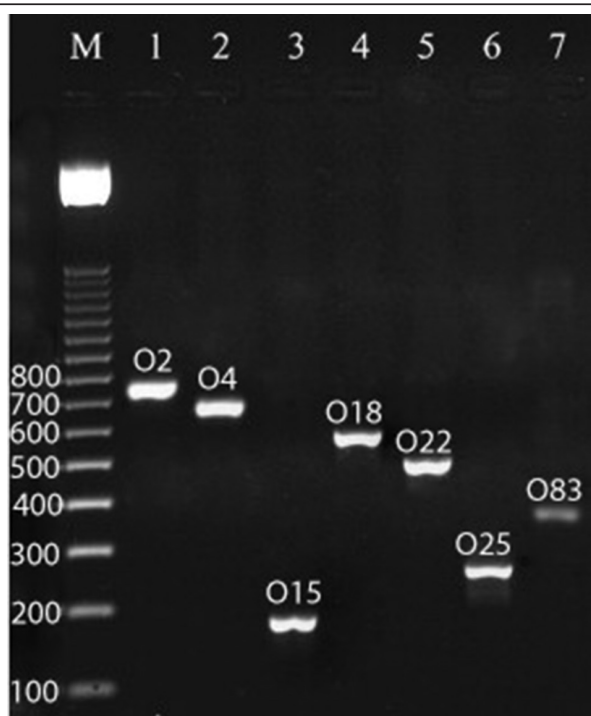

Figure 2. Multiplex PCR Assay for Detection of $\mathrm{O} 2, \mathrm{O} 4, \mathrm{O} 15, \mathrm{O} 18, \mathrm{O} 22, \mathrm{O} 25$, and 083 Serogroups of Uropathogenic Escherichia Coli Strains Isolated From Pediatrics With UTIs. Line M is 100 bp Ladders; $1-7$ Are Positive Samples

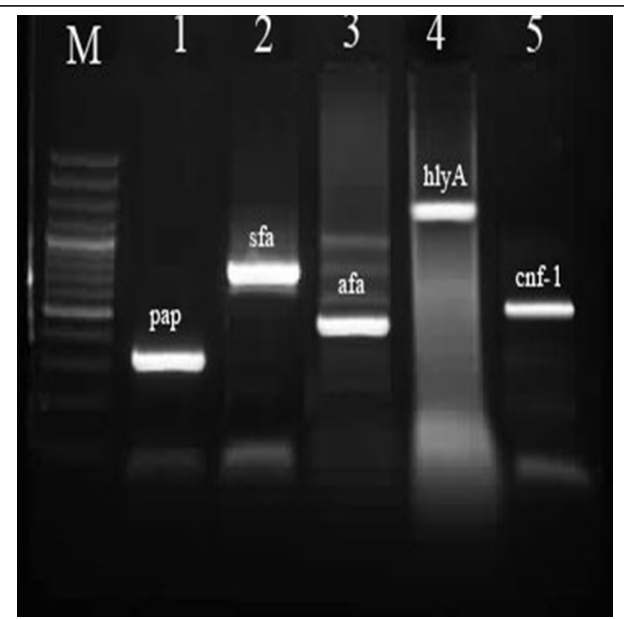

Figure 3. Multiplex PCR Assay for Detection of Virulence Genes of Uropathogenic Escherichia Coli Strains Isolated From Pediatrics With UTIs. Line M is 100 bp Ladder, 1-5 Are Positive Samples.

\section{Discussion}

The results of our investigation showed that girls were more prone to get UTIs than boys. Similar results were reported previously $(1,14-16)$. It is because of the relatively short, straight anatomy of the urethra in women. In addition, retrograde ascent of bacteria from the perineum is the most common cause of UTIs in women. Genetic factors, including expression of Lewis blood group Le (a+b-) and Le (a-b-) and HLA-A3 may also expose women at a higher risk for recurrent UTIs. Several O-Serogroups have been detected in urine samples of our study. Totally, $\mathrm{O} 1, \mathrm{O} 2, \mathrm{O} 4, \mathrm{O} 6, \mathrm{O} 18$ and $\mathrm{O} 25$ were the most commonly detected O- Serogroups in UPEC strains of our study. Similar results have been reported previously $(1,4,17)$. Fifty percent of UPEC strains of Molina-López et al. (2011) (18) investigations belonged to Serogroups O2, O1, O6, O4, O25, O75, and O8. Emamghoraishi et al. (2011) (19) reported that from a total of 96 strains of E. coli isolated from urine samples of Iranian children with UTIs, 12.2\% were $01,10.2 \%$ were $\mathrm{O} 6$ and $4.1 \%$ were 015 Serogroups. According to the results of Momtaz et al. (2013) (4), O25 (26.01\%), O15 (21.13\%), O4 (5.69\%), O1 (2.43\%), and O2 (2.43\%) were the most commonly detected Serogroups among Iranian hospitalized patients. Fathollahi et al.(2009) (16) reported that $66.14 \%$ of UPEC strains isolated from Iranian patients with UTIs belonged to O1, O18, O6, O20, and O15 Serogroups. The UPEC strains from a relatively small number of O Serogroups, mainly O1, O2, O4, O6, O18 and O25 were reported to account for a major part of O- Serogroups UTI strains from different parts of the world (1, $4,16)$. These Serogroups were isolated from the cases of pyelonephritis and cystitis previously $(1,20)$.

It has been repeatedly reported that $\mathrm{O} 1, \mathrm{O} 2, \mathrm{O} 4, \mathrm{O} 6$, O25, and $\mathrm{O} 18$ Serogroups possess specific virulence factors, which confer on their special adhesive and invasive abilities $(1,4)$. Most O- Serogroups of our study were pap+, cnf1+, hlyA+, sfa+, and afa+. Totally, Pap, cnf1 and hlyA were the most commonly detected virulence genes in our study. Similar Iranian studies have been reported previously by Arabi et al. (2012) (21), Karimian et al. (2012) (22), Asadi Karam et al. (2012) (23) and Emamghorashi et al. (2011) (19). Ninety two percent of UPEC strains of Arabi et al. (2012) (21) were harbored the fim and sfa genes, separately. Karimian et al. (2012) (22) reported that the distribution of pap, hlyA, cnfiand afa virulence genes were $50.4 \%, 50.4 \%, 50.4 \%$, and $8.13 \%$, respectively. The pap gene was detected in $80 \%$ of boys and $66.66 \%$ of girls of our study. This gene plays important roles in the pathogenesis of pyelonephritis and ascending UTIs 21. Production of cytokines and adhesion to tissue matrix and mucosa are performed by this gene (24). Attachment of pap gene to the epithelial receptor leads to the release of ceramide, which acts as an agonist of Toll-like receptor 4 (TLR4), a receptor involved in activation of the immune cell response (25). This event leads to the development of pain and local inflammation (26). 
The sfa gene was detected in $13.33 \%$ of boys and $26.66 \%$ of girls in our study. This gene is responsible for adhesion to the endothelial and epithelial cells of the lower urinary tract and kidney tissues (27). The sfa gene has also been detected in the E. coli strains, which causes sepsis, meningitis, and ascending UTIs. The cnfl gene was detected in $60 \%$ of boys and $55.55 \%$ girls in our investigation. This gene was produced by $1 / 3$ of all pyelonephritis strains, and may also be involved in kidney damages. Several investigations showed that this gene is responsible for polymorph nuclear phagocytosis and epithelial cells apoptosis (Mills et al., 2000). Also, bladder cell exfoliation and enhancement of bacterial access to underlying tissue are caused by the cnfi gene (28). The most important secreted virulence factor of UPEC strains is a lipoprotein called hlyA, which is associated with upper UTIs such as pyelonephritis $(29,30)$. Totally, $53.33 \%$ of boys and $40 \%$ of girls in our study had positive results for the hlyA gene. This toxin is able to lyse nucleated host cells to better cross mucosal barriers, damage effectors' immune cells, induce the apoptosis of T lymphocytes, neutrophils and renal cells, and gain enhanced access to host nutrients and iron stores (29-33). The afa gene was detected in $46.66 \%$ of boys and $20 \%$ girls in our study. Clinical findings recommend that UPEC strains with afa adhesins have characters potentially favoring the occurrence of pyelonephritis, recurrent and chronic UTIs (13). In conclusion, this study showed that UTIs especially in girls should be considered. Most examined Serogroups of our study had positive results for putative virulence factors. O1, O2, O6, $\mathrm{O} 4$ and O18 Serogroups and pap, cnf1 and hlyA virulence factors had highest frequencies for UPEC strains. Our study was the most widely report of direct detection of virulence factors and O-Serogroups of UPEC strains isolated from pediatric patients in Iran. The high prevalence of O1 Serogroups in children with UTIs and the high percentage of virulent genes in O1 Serogroups suggested a close relation between Serogroups and genotypes of UPEC strains.

\section{Acknowledgements}

This study was supported by AJA University of Medical Science, Tehran, Iran.

\section{Authors' Contributions}

The DNA extraction, PCR techniques, writing the manuscript, and supporting the project were performed by FSD, BD, EKH and HM, and samples collection, statistical analysis and hospital coordination were performed by $\mathrm{MJH}, \mathrm{RM}, \mathrm{VT}$ and EY. All authors read and approved the final manuscript.

\section{Financial Disclosure}

The authors declared that they had no competing interests.

\section{Funding/Support}

This work was supported by a grant (6-92-204-908965) from AJA University of Medical Science, Tehran, Iran and Islamic Azad University, Shahrekord Branch-Iran.

\section{References}

1. Jadhav S, Hussain A, Devi S, Kumar A, Parveen S, Gandham N, et al. Virulence characteristics and genetic affinities of multiple drug resistant uropathogenic Escherichia coli from a semi urban locality in India. PLoS One. 2011;6(3).

2. WHO . Urinary Tract Infections in Infants and Children in Developing Countries in the Context of IMCI. World Health Organization. Geneva Switzerland; 2005.

3. Foxman B. Epidemiology of urinary tract infections: incidence, morbidity, and economic costs. Dis Mon. 2003;49(2):53-70.

4. Momtaz H, Dehkordi FS, Rahimi E, Asgarifar A. Detection of Escherichia coli, Salmonella species, and Vibrio cholerae in tap water and bottled drinking water in Isfahan, Iran. BMC Public Health. 2013;13(1):556.

5. Soto SM, Guiral E, Bosch J, Vila J. Prevalence of the set-1B and astA genes encoding enterotoxins in uropathogenic Escherichia coli clinical isolates. Microb Pathog. 2009;47(6):305-7.

6. Bauer R, Zhang L, Foxman B, Siitonen A, Jantunen ME, Saxen $\mathrm{H}$, et al. Molecular epidemiology of 3 putative virulence genes for Escherichia coli urinary tract infection-usp, iha, and iroN(E. coli). J Infect Dis. 2002;185(10):1521-4.

7. Abe CM, Salvador FA, Falsetti IN, Vieira MA, Blanco J, Blanco JE, et al. Uropathogenic Escherichia coli (UPEC) strains may carry virulence properties of diarrhoeagenic E. coli. FEMS Immunol Med Microbiol. 2008;52(3):397-406.

8. Ananias M, Yano T. Serogroups and virulence genotypes of Escherichia coli isolated from patients with sepsis. Braz J Med Biol Res. 2008;41(10):877-83.

9. Bidet P, Mahjoub-Messai F, Blanco J, Blanco J, Dehem M, Aujard Y et al. Combined multilocus sequence typing and O serogrouping distinguishes Escherichia coli subtypes associated with infant urosepsis and/or meningitis. J Infect Dis. 2007;196(2):297-303.

10. Yamamoto S. Molecular epidemiology of uropathogenic Escherichia coli. J Infect Chemother. 2007;13(2):68-73.

11. Li D, Liu B, Chen M, Guo D, Guo X, Liu F, et al. A multiplex PCR method to detect 14 Escherichia coli serogroups associated with urinary tract infections. J Microbiol Methods. 2010;82(1):71-7.

12. Yamamoto S, Terai A, Yuri K, Kurazono H, Takeda Y, Yoshida O. Detection of urovirulence factors in Escherichia coli by multiplex polymerase chain reaction. FEMS Immunol Med Microbiol. 1995;12(2):85-90.

13. Le Bouguenec C. Adhesins and invasins of pathogenic Escherichia coli. Int J Med Microbiol. 2005;295(6-7):471-8.

14. Shaikh N, Morone NE, Bost JE, Farrell MH. Prevalence of urinary tract infection in childhood: a meta-analysis. Pediatr Infect Dis J. 2008;27(4):302-8.

15. Vollmerhausen TL, Ramos NL, Gundogdu A, Robinson W, Brauner A, Katouli M. Population structure and uropathogenic virulenceassociated genes of faecal Escherichia coli from healthy young and elderly adults. J Med Microbiol. 2011;60(Pt 5):574-81.

16. Fathollahi S, Yousefi_Mashouf R, Goodarzi MT, Hajilooei M, Hemati S, Mostafaei A, et al. Typing of the uropathogenic E. coli strains using. Iranian J Clin Infect Dis. 2009;4(2):77-81.

17. Hagan EC, Mobley HL. Uropathogenic Escherichia coli outer membrane antigens expressed during urinary tract infection. Infect Immun. 2007;75(8):3941-9.

18. Molina-Lopez J, Aparicio-Ozores G, Ribas-Aparicio RM, GavilanesParra S, Chavez-Berrocal ME, Hernandez-Castro R, et al. Drug resistance, serotypes, and phylogenetic groups among uropathogenic Escherichia coli including O25-ST131 in Mexico City. J Infect Dev Ctries. 2011;5(12):840-9.

19. Emamghoraishi F, Farshad S, Kalani M. Relationship between O serotype and virulent genes in Escherichia coli causing urinary tract infections. Iran J Kidney Dis. 2011;5(4):234-7. 
20. Takahashi A, Kanamaru S, Kurazono H, Kunishima Y, Tsukamoto $\mathrm{T}$, Ogawa O, et al. Escherichia coli isolates associated with uncomplicated and complicated cystitis and asymptomatic bacteriuria possess similar phylogenies, virulence genes, and O-serogroup profiles. J Clin Microbiol. 2006;44(12):4589-92.

21. Arabi S. The Common Fimbarie genotyping in Uropathogenic Escherichia coli. Ann Biol Res. 2012;3(10):4951-4

22. Momtaz H, Karimian A, Madani M, Safarpoor Dehkordi F, Ranjbar R, Sarshar M, et al. Uropathogenic Escherichia coli in Iran: serogroup distributions, virulence factors and antimicrobial resistance properties. Ann Clin Microbiol Antimicrob. 2013;12:8.

23. Asadi KM, Oloomi M, Habibi M, Bouzari S. Cloning of fimH and fliC and expression of the fusion protein FimH/FliC from Uropathogenic Escherichia coli (UPEC) isolated in Iran. Iran J Microbiol. 2012;4(2):55-62.

24. Godaly G, Bergsten G, Frendeus B, Hang L, Hedlund M, Karpman $\mathrm{D}$, et al. Innate defences and resistance to gram negative mucosal infection. Adv Exp Med Biol. 200 0;485:9-24.

25. Fischer H, Ellstrom P, Ekstrom K, Gustafsson L, Gustafsson M, Svanborg C. Ceramide as a TLR4 agonist; a putative signalling intermediate between sphingolipid receptors for microbial ligands and TLR4. Cell Microbiol. 2007;9(5):1239-51.

26. Bergsten G, Wullt B, Svanborg C. Escherichia coli, fimbriae, bacterial persistence and host response induction in the human urinary tract. Int J Med Microbiol. 2005;295(6-7):487-502.
27. Mulvey MA. Adhesion and entry of uropathogenic Escherichia coli. Cell Microbiol. 2002;4(5):257-71.

28. Mills M, Meysick KC, O'Brien AD. Cytotoxic necrotizing factor type 1 of uropathogenic Escherichia coli kills cultured human uroepithelial 5637 cells by an apoptotic mechanism. Infect Immun. 2000;68(10):5869-80.

29. Bien J, Sokolova O, Bozko P. Role of Uropathogenic Escherichia coli Virulence Factors in Development of Urinary Tract Infection and Kidney Damage. Int J Nephrol. 2012;2012:681473.

30. Los FC, Randis TM, Aroian RV, Ratner AJ. Role of pore-forming toxins in bacterial infectious diseases. Microbiol Mol Biol Rev. 2013;77(2):173-207.

31. Chen M, Jahnukainen T, Bao W, Dare E, Ceccatelli S, Celsi G. Uropathogenic Escherichia coli toxins induce caspase-independent apoptosis in renal proximal tubular cells via ERK signaling. Am J Nephrol. 2003;23(3):140-51.

32. Smith YC, Grande KK, Rasmussen SB, O'Brien AD. Novel threedimensional organoid model for evaluation of the interaction of uropathogenic Escherichia coli with terminally differentiated human urothelial cells. Infect Immun. 2006;74(1):750-7.

33. Russo TA, Davidson BA, Genagon SA, Warholic NM, Macdonald U, Pawlicki PD, et al. E. coli virulence factor hemolysin induces neutrophil apoptosis and necrosis/lysis in vitro and necrosis/lysis and lung injury in a rat pneumonia model. Am J Physiol Lung Cell Mol Physiol.2005;289(2):L207-16. 